\title{
Methanolic Extract of Myrsine africana Leaf Ameliorates Hyperglycemia and Dyslipidemia in Alloxan-Induced Diabetic Albino Mice
}

\author{
Yosef Eshetie Amare \\ Department of Biomedical Sciences, Institute of Medicine and Health Sciences, Debre Berhan University, Debre Berhan, Ethiopia \\ Correspondence should be addressed to Yosef Eshetie Amare; yophy2006@gmail.com
}

Received 28 September 2021; Revised 20 November 2021; Accepted 10 December 2021; Published 29 December 2021

Academic Editor: José Roberto Santin

Copyright (c) 2021 Yosef Eshetie Amare. This is an open access article distributed under the Creative Commons Attribution License, which permits unrestricted use, distribution, and reproduction in any medium, provided the original work is properly cited.

\begin{abstract}
Background. Diabetes mellitus is one of the leading public health problems globally, and its prevalence is increasing in Ethiopia. The current drugs for people with diabetes are costly, less effective, and less safe with a challenging administration method. Thus, globally, the need for alternative herbal antidiabetic medicines is increasing. In the previous studies, antioxidant activities have been seen in crude extracts of $M$. africana leaves, which is an auspicious sign of antidiabetic property. Accordingly, this study has evaluated the antidiabetic and antidyslipidemic activities of methanolic extract of $M$. africana leaves. Methods. Hypoglycemic and antihyperglycemic activities of the three doses $(250 \mathrm{mg} / \mathrm{kg}, 500 \mathrm{mg} / \mathrm{kg}$, and $1000 \mathrm{mg} / \mathrm{kg})$ of crude methanolic extract of M. africana leaf were studied on normoglycemic, oral glucose-loaded, and alloxan-induced diabetic mice models. The effect of the extract on diabetic dyslipidemia, insulin and glycated hemoglobin levels, carbohydrate-metabolizing enzymes, and body weight was also studied in alloxan-induced diabetic mice. Glibenclamide $(5 \mathrm{mg} / \mathrm{kg})$ was used as a standard drug in all cases. Data analysis was carried out using mixed-design ANOVA. A $P$ value of $\leq 0.05$ was considered a statistically significant difference. Results. The methanolic extract of $M$. africana leaf did not show acute toxicity up to the dose of $5000 \mathrm{mg} / \mathrm{kg}$ and showed better glucose utilization in the oral glucose tolerance test. After 14 days of treatment, $M$. africana leaf extract decreased the blood glucose level, glycated hemoglobin, glucose-6-phosphatase, and fructose-1-6-bisphosphatase in diabetic mice. In contrast, it increased hexokinase and insulin levels in diabetic mice. Moreover, weight loss and dyslipidemia profiles have been corrected significantly in diabetic mice. Conclusion. M. africana leaves showed antihyperglycemic and antidyslipidemic effects in alloxan-induced diabetic mice. That suggests $M$. africana may be a potential treatment option for diabetes in the future. However, further molecular studies are required to analyze the mechanisms.
\end{abstract}

\section{Introduction}

Diabetes mellitus (DM) is a group of metabolic disorders characterized by increased blood glucose levels due to the absence of insulin secretion or defects in insulin action. It is becoming a worldwide public health problem leading to macro- and microvascular complications [1]. Moreover, hypercholesterolemia and hypertriglyceridemia are common complications of DM. In addition, elevated serum triglycerides, total cholesterol, and low serum high-density lipoprotein cholesterol levels exist in diabetic patients compared with nondiabetic individuals.
DM currently exerts a significant burden in the subSaharan region and is expected to increase. Many diabetic patients face significant challenges accessing diagnosis and treatment. This contributes to a high prevalence of mortality and complications [2]. Around 463 million people in the age group between 20 and 79 years have DM worldwide, which is predicted to increase to 700 million by 2045 [3].

Treatment of DM without side effects remained a challenge for the scientific community. As an example, the production of lactic acidosis, hypoglycemia, malabsorption, and weight gain or loss are shortcomings of contemporary 
antidiabetic medicines [4]. Therefore, exploring safer and more effective antidiabetic drugs is needed.

Globally, medicinal plants have been used as a source of modern medicine. About $80-85 \%$ of the world population relies on herbal extracts to treat diseases [5]. Historically, modern antidiabetic drugs were discovered from medicinal plants. One of the examples is Galega officinalis, that metformin was isolated from it [6].

Myrsine africana (M. africana), also called Cape Myrtle or African boxwood, belongs to the family Myrsinaceae and is an evergreen shrub growing to $2 \mathrm{~m}$ at a slow rate. The plant is native to Africa and Asia and usually grows well in dry parts [7].

Plant-derived secondary metabolites such as flavonoids, alkaloids, and phenolic compounds have a blood glucosereducing ability [8-13]. Antihyperglycemic and antidyslipidemic effects of these plants are attributed to their ability to restore the function of pancreatic tissues by causing an increase in insulin production or inhibiting the intestinal absorption of glucose or the facilitation of metabolites in the insulin-dependent process. In hyperglycemic conditions, continuous generation of reactive oxygen species occurred. Reactive oxygen species increased oxidative stress mainly due to the overproduction of oxygen free radicals. The induction of oxidative stress is the leading cause of the advanced disease process of $\mathrm{DM}[8,14,15]$. Antioxidants play an important role in hunting the free radicals, damaging the reactive oxygen species, and protecting the human body from oxidative stress. Therefore, scavenging of free radicals by antioxidants is one of the treatment and prevention strategies of DM $[8,15,16]$.

The presence of saponins, flavonoids, tannins, and steroidal and phenolic compounds has been shown in the methanolic extract of $M$. africana leaf. Moreover, the result demonstrated that the extract of $M$. africana has intense antioxidant activity [17]. The in vitro study showed that $M$. africana has a vigorous antioxidant activity, which is a sign of promising antidiabetic activity $[18,19]$. M. africana has shown a potential therapeutic effect for helminths, bacteria, and antitumor activities $[20,21]$. However, the antidiabetic activity of M. africana is hitherto unknown. The antidiabetic and antidyslipidemic activities of $M$. africana leaf methanolic extract in alloxan-induced diabetic mice were evaluated in this study.

\section{Materials and Methods}

2.1. Drugs, Chemicals, and Instruments. This study used the following drugs, chemicals, and instruments: alloxan (Sigma Aldrich, Germany), methanol absolute (Nice Chemicals, India), glibenclamide (Julphar Pharmaceuticals, Ethiopia), normal saline (Addis Pharmaceutical Factory, Ethiopia), $40 \%$ glucose solution (Addis Pharmaceutical Factory, Ethiopia), PRODIGY ${ }^{\circledast}$ blood glucose meter and strips (OK Biotech Co., Ltd., Taiwan), and Mindray BS-240 clinical chemistry analyzer (Shenzhen Mindray Bio-Medical Electronics Co., Ltd, China). All other chemicals used were of analytical grade.
2.2. Plant Material Collection and Extraction. The permission was obtained from Debre Berhan University institutional review board committee members (Dr. Esubalaew Tesfahun, Dr. Amare Ayalew, and Dr. Gezahegn Degafe). Fresh leaves of $M$. africana were collected from Ankober, North Shewa Zone of Amhara Region, Ethiopia, in May 2019. The use of plant parts in the present study complies with international, national, or institutional guidelines. The plant specimen was kept at the Herbarium of Addis Ababa University with the voucher number ATA0001 after taxonomic identification and authentication by Dr. Abiyou Tilahun. Then, dried fresh leaves $(100 \mathrm{~g})$ of the plant material were macerated, stayed for five days in stoppered conical flasks containing $200 \mathrm{ml}$ of methanol, and filtered. The filtrate was dried under reduced pressure using a rotary evaporator to yield $3 \mathrm{~g}$ of crude extract. The weighed crude extract was stored at $-4^{\circ} \mathrm{C}$ until used.

2.3. Experimental Animals. A total of 106 healthy Swiss albino mice of both sexes weighing 20-30 g were used in this study. This study was done following the ARRIVE guidelines. The animals were purchased from the Ethiopian Public Health Institute, Addis Ababa, Ethiopia. The animals were housed using standard cages and kept under normal conditions (12-hour light and 12-hours dark cycle) at the Department of Pharmacology, Addis Ababa University. The mice were acclimatized for seven days before the experiment and given a standard diet and water ad libitum.

\subsection{Phytochemical Screening of M. africana Leaf Crude} Extract. The absence or presence of terpenoids, steroids, flavonoids, glycosides, tannins, saponins, phenols, alkaloids, and anthraquinones was assessed in a crude extract of M. africana leaf using standard protocols.

Salkowski's test was applied to identify the presence of terpenoids. The methanolic extract $(100 \mathrm{mg})$ of $M$. africana was dissolved in $5 \mathrm{ml}$ of distilled water. The solution was mixed in $2 \mathrm{ml}$ of chloroform and $3 \mathrm{ml}$ of concentrated sulfuric acid. The formation of a reddish-brown color layer at the interface indicated the presence of terpenoids.

Braemer's test was applied for the detection of tannins. In a test tube, $0.25 \mathrm{~g}$ of the crude extract was stirred with $10 \mathrm{ml}$ distilled water and filtered with filter paper (Whatman No. 1). Few drops of $2 \%$ ferric chloride were added to the filtrate. The filtrate was checked for green precipitation as an indication of the presence of tannins.

The Froth test was used to detect saponins. Five milliliters of distilled water and $0.25 \mathrm{~g}$ of the crude extract were added to a test tube. For 2 minutes, the solution was shaken robustly until a firm, persistent froth was seen. Froth formation indicates the existence of saponins.

The presence of anthraquinones was checked using Borntrager's test. $3 \mathrm{ml}$ of the plant extract was dissolved in $3 \mathrm{ml}$ of benzene and filtered with Whatman No. 1 filter paper. Then, $2 \mathrm{ml}$ of $10 \%$ ammonium hydroxide was added. Purple ring formation will reveal anthraquinone's presence in the extract. 
Detection of steroids was done using the Liebermann-Burchard test. The methanolic crude extract $(0.5 \mathrm{~g})$ was dissolved in $2 \mathrm{ml}$ of distilled water in a test tube. Then, $2 \mathrm{ml}$ of chloroform and sulfuric acid were added to the solution. The formation of red color at the lower layer of the chloroform layer indicated the presence of steroids.

Wagner's test was applied to detect the presence of alkaloids. Three drops of Wagner's reagent were added to $10 \mathrm{mg}$ of the crude extract and dissolved in distilled water. Reddish-brown color formation reveals the presence of alkaloids.

The ferric chloride test was used to detect phenolic compounds. $0.5 \mathrm{ml}$ of neutral $5 \%$ ferric chloride solution was added to the dissolved $10 \mathrm{mg}$ crude extract with $1 \mathrm{ml}$ distilled water. The blue-green color formation is indicative of the presence of phenolic compounds.

$\mathrm{NaOH}$ was used for the flavonoids test. Nearly $0.3 \mathrm{~g}$ of the crude extract was dissolved in $2 \mathrm{ml}$ distilled water. Three drops of $20 \% \mathrm{NaOH}$ solution were added to the solution. The presence of flavonoids is confirmed when the yellow color of the solution changed colorless after adding three drops of $20 \%$ hydrochloric acid.

Detection of glycosides was done using the Keller-Kiliani test. $20 \mathrm{ml}$ of distilled water was used to dissolve $0.5 \mathrm{~g}$ of the dried crude extract in a test tube. The solution was filtered by Whatman No.1 filter paper after $24 \mathrm{hr} .5 \mathrm{ml}$ of the filtrate was treated with $2 \mathrm{ml}$ of concentrated glacial acetic acid and two drops of $0.1 \%$ ferric chloride solution. The mixture was poured into a test tube of $1 \mathrm{ml}$ concentrated sulfuric acid. The brown ring formation at the interface is indicative of glycoside's presence in the extract [22-24].

\subsection{Determination of Total Phenolic Content in M. africana.} The Folin-Ciocalteu reagent was used to determine the total phenolic content. $200 \mu \mathrm{g} / \mathrm{ml}$ of the extract was mixed with $400 \mu \mathrm{l}$ of the Folin-Ciocalteu reagent and $1.5 \mathrm{ml}$ of $20 \%$ sodium carbonate. The mixture was shaken thoroughly and made up to $10 \mathrm{ml}$ with distilled water. After 2 hours, the absorbance of the mixture was measured at $765 \mathrm{~nm}$. The total concentration of phenol in $M$. africana extract was determined from the standard curve of gallic acid and was expressed as mg of gallic acid equivalent per gm of dried plant extract.

\subsection{Determination of Total Flavonoid Content in M. africana.} $1 \mathrm{ml}$ of the methanolic extract $(200 \mu \mathrm{g} / \mathrm{ml})$ was mixed with $1 \mathrm{ml}$ aluminum trichloride in $20 \mathrm{mg} / \mathrm{ml}$ methanol. A drop of acetic acid was added and then diluted with methanol to $20 \mathrm{ml}$. The solution was filtered through Whatman filter paper No. 1 before measuring the absorbance. Then, absorbance was measured at $415 \mathrm{~nm}$ against blank after 45 minutes. The total flavonoid content in $M$. africana was determined from the standard quercetin curve and was expressed as mg of quercetin equivalent per gm of dried plant extract.

2.7. Antioxidant Activity of M. africana Extract by DPPH Free Radical Scavenging Assay. The DPPH (2, 2 diphenyl-1picrylhrazyl) free radical scavenging method was used to assess the antioxidant property of $M$. africana. Ascorbic acid was used as a control assuming that it has $100 \%$ free radical scavenging activity. $2.8 \mathrm{ml}$ of DPPH solution $(45 \mu \mathrm{g} / \mathrm{ml})$ was promptly added in $200 \mu \mathrm{l}$ of methanol solution of plant extract at different concentrations in test tubes. The solution was thoroughly mixed and kept for 30 minutes at room temperature. Finally, the absorbance was measured at $517 \mathrm{~nm}$ against methanol solution used as a blank. The percentage of scavenging of DPPH free radical is calculated using the following formula:

$$
\left\{\frac{\left(A_{0}-A_{1}\right)}{A_{0}}\right\} \times 100,
$$

where $A_{0}=$ absorbance of the control and $A_{1}=$ absorbance of the extract/standard. Then, the percentage of inhibition was plotted against log concentration and $\mathrm{IC}_{50}$ was calculated from the graph.

2.8. Acute Oral Toxicity Study. An acute oral toxicity study of M. africana was performed based upon the organization for Economic Cooperation and Development (OECD) 425 guidelines [25]. Five female albino mice weighing 20-30 grams were used. After 4 hours fasting, a single mouse received $2000 \mathrm{mg} / \mathrm{kg}$ of the leaf extract orally and was left under careful observation for behavioral or/and physical changes for 24 hours. The remaining four female mice received the same dose, and strict follow-up continued until the end of fourteen days for potential signs of toxicity and mortality. The dose of the extract was increased to $5000 \mathrm{mg} /$ $\mathrm{kg}$, and a similar procedure was followed on another five female mice.

2.9. Induction of Diabetes. Alloxan (2,4,5,6-tetraoxypyrimidine; 5,6-dioxyuracil) was administered to induce diabetes. Before alloxan administration, the mice have been subjected to sixteen hours of fasting. Fresh alloxan solution was prepared using normal saline $(0.9 \%)$ and administered intraperitoneally at the dose of $150 \mathrm{mg} / \mathrm{kg}$ according to previous studies [26-28]. The mice were screened for glucose levels after 72 hours of alloxan administration. Animals with fasting blood glucose levels $>200 \mathrm{mg} / \mathrm{dl}$ were included in the study as diabetic mice [28-30]. After the screening, diabetic mice were randomly allocated to the different test groups.

2.10. Designs and Procedures of the Experiment. For the hypoglycemic, oral glucose tolerance, and single-dose treatment, the following testing groups were used, with six mice in each group: a negative control group (NS $10 \mathrm{ml} / \mathrm{kg}$ group or normal control), received $10 \mathrm{ml} / \mathrm{kg} \mathrm{NS}$; a positive control group (GLC $5 \mathrm{mg} / \mathrm{kg}$ group), treated with glibenclamide $(5 \mathrm{mg} / \mathrm{kg})$; and three MA-treated groups, received 250, 500, and $1000 \mathrm{mg} / \mathrm{kg} \mathrm{MA}$, which are MA $250 \mathrm{mg} / \mathrm{kg}$ group, MA $500 \mathrm{mg} / \mathrm{kg}$ group, and MA $1000 \mathrm{mg} / \mathrm{kg}$ group, respectively.

For the repeated daily dose treatment test, the following groups were used, with six mice in each group: a diabetic control mice group (diabetic control), received $10 \mathrm{ml} / \mathrm{kg} \mathrm{NS}$; 
a nondiabetic negative control group (normal control), received $10 \mathrm{ml} / \mathrm{kg}$ NS; a positive control mice group (GLC $5 \mathrm{mg} / \mathrm{kg}$ group), treated with glibenclamide $(5 \mathrm{mg} / \mathrm{kg}$ ); and three MA-treated groups, received 250, 500, and $1000 \mathrm{mg} / \mathrm{kg}$ MA, which are MA $250 \mathrm{mg} / \mathrm{kg}$ group, MA $500 \mathrm{mg} / \mathrm{kg}$ group, and MA $1000 \mathrm{mg} / \mathrm{kg}$ group, respectively.

Plant extract doses were determined based on acute oral toxicity results. The middle dose $500 \mathrm{mg} / \mathrm{kg}$ was one-tenth of the limit dose $(5000 \mathrm{mg} / \mathrm{kg})$, the higher dose $1000 \mathrm{mg} / \mathrm{kg}$ was twice the middle dose, and the lower dose $250 \mathrm{mg} / \mathrm{kg}$ was calculated as half of the middle dose The respective amount of the plant extract was administered orally to each animal after dissolving it with normal saline at a volume of not more than $10 \mathrm{ml} / \mathrm{kg}$ of body weight [31].

2.11. Determination of Blood Glucose Level. Blood samples were collected from the tail vein of each animal using an aseptic technique. According to the operating procedures, the blood glucose level was determined using the PRODIGY ${ }^{\circledR}$ blood glucose meter and strips (OK Biotech Co., Ltd., Taiwan). The test was done in triplicate.

For the hypoglycemic test, each group of mice received their respective treatment after overnight fasting. The BGL was measured at zero (just before treatment), one, two, four, and six hours after treatment $[32,33]$. For the glucose tolerance test, glucose solution $(40 \% \mathrm{w} / \mathrm{v})$ was given orally to each animal at the dose of $2.5 \mathrm{~g} / \mathrm{kg}$ after they got their respective treatment $[32,34]$. Then, the BGL was measured at zero, 30, 60, and 120 minutes [32, 33]. For the single-dose antihyperglycemic test, overnight fasted diabetic mice received normal saline, $M$. africana leaf extract, and glibenclamide according to their groupings. Then, the BGL was recorded at zero (just before treatment), two, four, six, and eight hours $[32,33]$. For the repeated daily dose antihyperglycemic test, mice were treated for 14 days based on their respective treatments. The BGL was recorded for each animal just before starting the treatment, on the first day of treatment (72 hours after alloxan administration) as a baseline, and on the seventh and fourteenth day. The mice were subjected to sixteen hours of fasting ahead of each sample collection [35].

2.12. Assessing the Body Weight and Serum Lipid Level Change on Repeated Daily Dose M. africana-Treated Diabetic Mice. The body weight of each animal was recorded just before the commencement of treatment, on the first day ( 72 hours after alloxan administration), and on the seventh and fourteenth day of respective therapy. After 14 days of treatment, the mice were euthanized using intraperitoneal (IP) injection of sodium pentobarbitone at a dose of $150 \mathrm{mg} / \mathrm{kg}[35,36]$. Then, the blood specimen was collected using a sterile gel tube via cardiac puncture. The blood samples were kept at room temperature for two hours and centrifuged. The serum lipid profiles, such as high-density lipoprotein, total cholesterol, and triglycerides, were measured using the Mindray BS-240 clinical chemistry analyzer (Shenzhen Mindray BioMedical Electronics Co., Ltd, China).
2.13. Biological Assays. The mice were anesthetized using sodium pentobarbitone. The blood sample of each mouse was collected using cardiac puncture and preserved with anticoagulant agents. The glycated hemoglobin was estimated according to the method of Nayak and Pattabiraman [37]. The insulin level was measured using an Insulin-1 ELISA kit (Sigma-Aldrich Germany). After 30 minutes, the color developed was measured at $450 \mathrm{~nm}$. The test standard was done in duplicate.

A portion of the liver was dissected and washed out with saline immediately and was homogenized in $0.1 \mathrm{M} \mathrm{HCl}$ buffer $(\mathrm{pH} 7.4)$. The homogenate was centrifuged at 10 $000 \mathrm{rpm}$ to remove the debris, and the supernatant was used as an enzyme source for the assays of hexokinase [38], glucose-6-phosphatase [39], and fructose-1-6-bisphospahatase [40].

2.14. Data Management and Analysis. Data were recorded, summarized, and analyzed using SPSS, version 21, software (USA). The mean and standard deviation (SD) were calculated, and the association between and within groups was determined using mixed-design ANOVA. A $P$ value of $\leq 0.05$ was considered indicative of a statistically significant difference.

\section{Results}

3.1. Phytochemical Screening. The phytochemical screening test of $M$. africana leaf crude extract showed the presence of terpenoids, steroids, flavonoids, glycosides, tannins, saponins, phenols, and alkaloids, as indicated in Table 1.

\subsection{Quantitative Determination of Phenols and Flavonoids in} M. africana. As indicated in Table 2, the total phenolic content was $40.34 \pm 2.51 \mathrm{mg}$ gallic acid equivalents per gram of $M$. africana extract, and the total flavonoid content was $36.28 \pm 4.13 \mathrm{mg}$ of quercetin equivalents per gram of M. africana extract.

\subsection{Effect of M. africana on DPPH Free Radical Scavenging} Activity. The ability of $M$. africana on decreasing the production of DPPH free radicals is shown in Figure 1. Ascorbic acid, used as a standard, was extremely operative in inhibiting the DPPH free radicals, showing an IC50 of $13.21 \mu \mathrm{g} / \mathrm{ml}$, while the IC50 of M. africana was found to be $75.32 \mu \mathrm{g} / \mathrm{ml}$.

3.4. Acute Oral Toxicity Study. M. africana methanolic leaf extract did not cause mortality in mice up to $5000 \mathrm{mg} / \mathrm{kg}$ dose. None showed signs of toxicity (behavioral, neurological, or autonomic) in the first 24 hours up to 14 days of study duration. The $\mathrm{LD}_{50}$ of the $M$. africana leaf extract might be more than $5000 \mathrm{mg} / \mathrm{kg}$.

3.5. Hypoglycemic Activity of M. africana Methanolic Leaf Extract in Normoglycemic Mice. In all test groups, the baseline BGL was not different significantly when compared 
TABLE 1: Phytochemical screening of $M$. africana leaf crude extract.

\begin{tabular}{lcc}
\hline List of metabolites & Tests used & Results \\
\hline Terpenoids & Salkowski's test & + \\
Steroids & Liebermann-Burchard test & + \\
Flavonoids & NaOH test & + \\
Glycosides & Keller-Kiliani test & + \\
Anthraquinones & Borntrager's test & - \\
Tannins & Braemer's test & + \\
Saponins & Froth test & + \\
Phenols & Ferric chloride & + \\
Alkaloids & Wagner's test & + \\
\hline
\end{tabular}

+, indicates test positive; ---, indicates test negative.

TABLE 2: Total phenolic and flavonoid content in $M$. africana leaf methanolic extract.

\begin{tabular}{lr}
\hline Parameters & Mean \pm SD \\
\hline Total phenolic content (mg of gallic acid equivalent/gm of dried plant extract) & $40.34 \pm 2.51$ \\
Total flavonoid content (mg of quercetin equivalent/gm of dried extract) & $36.28 \pm 4.13$ \\
\hline
\end{tabular}

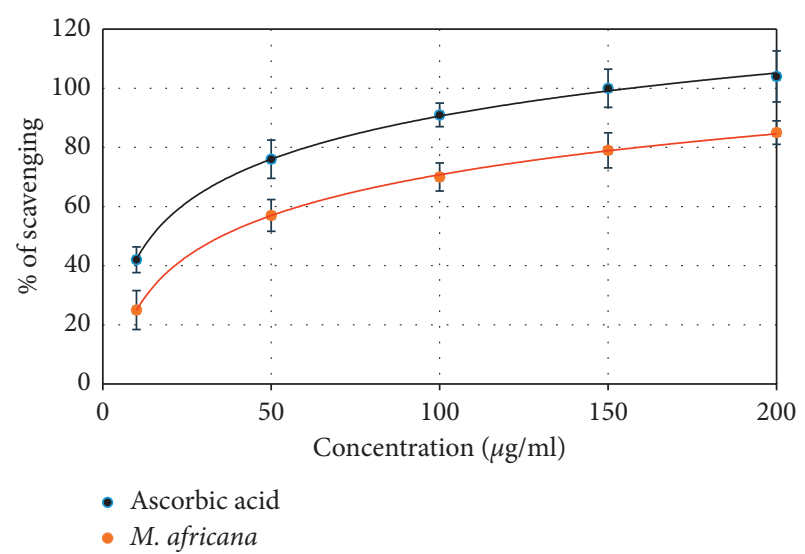

FIGURE 1: DPPH free scavenging (\%) at various concentrations $(\mu \mathrm{g} / \mathrm{ml})$ of $M$. africana leaf methanolic extract and ascorbic acid. The antioxidant activity of the extract was estimated by the $\mathrm{IC}_{50}$ value.

with each other (Table 3). At all time points, no statistical difference of BGL was seen between all the $M$. africanatreated groups and negative control groups (Figure 2); but the BGL of the glibenclamide $(5 \mathrm{mg} / \mathrm{kg})$-treated group significantly decreased compared with that of the negative control group. Moreover, a statistically significant reduction of BGL was seen in the GLC-treated group when compared with all the $M$. africana-treated groups. At all time points, the BGL of all the M. africana-treated groups did not show a statistical difference when compared with each other. At all time points, there was no significant reduction of BGL in all three doses of the plant extract and normal saline-treated groups compared with the corresponding baseline level. However, the BGL in the GLC-treated group significantly decreased at the $1^{\text {st }}(P<0.01), 2^{\text {nd }}, 4^{\text {th }}$, and $6^{\text {th }}(P<0.001)$ hours compared with the initial level.

3.6. Antihyperglycemic Activity of the Methanolic Leaf Extract of M. africana in Oral Glucose-Loaded Mice. As indicated in Table 4, the baseline BGL in all groups did not show a statistical difference when compared with each other. In all groups, a statistically significant $(P<0.001)$ increment of BGL was observed thirty minutes after oral glucose loading of each mouse (Figure 3). In all groups, after glucose loading, the BGL at the first and second hours has shown significant $(P<0.001)$ decrement when compared with the thirtyminute blood glucose level. In the first hour, MA $1000 \mathrm{mg} / \mathrm{kg}$ $(P<0.001)$ and MA $500 \mathrm{mg} / \mathrm{kg}(P<0.01)$ have reduced hyperglycemia significantly when compared with the negative control. In the GLC-treated group, the state of hyperglycemia significantly reduced at the $1^{\text {st }}(P<0.001)$ and $2^{\text {nd }}(P<0.01)$ hours when compared with the normal salinetreated group. The BGL did not show significant differences in all the M. africana-treated groups when compared with each other. At the first and second hours, the BGL was significantly $(P<0.001)$ reduced in the GLC-treated group when compared with all the $M$. africana-treated groups.

3.7. Antihyperglycemic Activity of Single Dose of M. africana Methanolic Leaf Extract in Diabetic Mice. At all time points, there was no significant BGL reduction seen in M. africanatreated groups when compared with the negative control group (Figure 4 and Table 5). However, the BGL was significantly decreased in the GLC-treated group at $4^{\text {th }}$ $(P<0.05), 6^{\text {th }}(P<0.05)$, and $8^{\text {th }}(P<0.001)$ hours when compared with the negative control group. Moreover, the BGL has shown substantial decrement at the second, fourth, and eighth hours in the GLC-treated group when compared with $M$. africana-treated groups. In the GLC-treated group, there was a significant reduction in the BGL at the $4^{\text {th }}, 6^{\text {th }}$, and $8^{\text {th }}$ hours when compared with its baseline level.

3.8. Antihyperglycemic Activity of Repeated Daily Dose of M. africana Methanolic Leaf Extract in Diabetic Mice. As indicated in Table 6 , the baseline BGL was not significantly different in all diabetic mice groups when compared with each other. However, the BGL in the diabetic groups was significantly elevated $(P<0.001)$ when compared with the 
TABLE 3: Hypoglycemic activity of the methanolic extract of $M$. africana leaf in normoglycemic mice.

\begin{tabular}{lccccc}
\hline \multirow{2}{*}{ Group } & \multicolumn{4}{c}{ Fasting blood glucose level (mg/dl) } \\
& $0 \mathrm{hr}$ & $1 \mathrm{hr}$ & $2 \mathrm{hr}$ & $4 \mathrm{hr}$ & $6 \mathrm{hr}$ \\
\hline NS $10 \mathrm{ml} / \mathrm{kg}$ & $89.1 \pm 5.1$ & $90.1 \pm 4$ & $83.6 \pm 5.7$ & $93.3 \pm 4.9$ & $84.3 \pm 6.3$ \\
MA $250 \mathrm{mg} / \mathrm{kg}$ & $86.6 \pm 3.3$ & $90.6 \pm 6.4$ & $85.1 \pm 6.3$ & $94.6 \pm 5.7$ & $85.8 \pm 6.4$ \\
MA $500 \mathrm{mg} / \mathrm{kg}$ & $85.8 \pm 5.5$ & $88.5 \pm 3.3$ & $87.1 \pm 5.3$ & $88.6 \pm 5.7$ & $87 \pm 6$ \\
MA $1000 \mathrm{mg} / \mathrm{kg}$ & $89.1 \pm 5.9$ & $90.8 \pm 6.1$ & $87.3 \pm 6.3$ & $92.3 \pm 3.8$ & $85.3 \pm 6.9$ \\
GLC $5 \mathrm{mg} / \mathrm{kg}$ & $89.8 \pm 3.7$ & $81.1 \pm 3.3^{\mathrm{aE} \mathrm{bE} \mathrm{dE} \beta F}$ & $68.8 \pm 4.1^{\mathrm{aF} \text { bG cG dG } \beta G}$ & $67.6 \pm 3.38^{\mathrm{aG} \mathrm{bG} \text { cG dG } \beta G}$ & $57.1 \pm 3.7^{\mathrm{aG} \mathrm{bG} \text { cG } \beta G}$ \\
\hline
\end{tabular}

Values are expressed as mean $\pm \mathrm{SD} ; n=6 ;{ }^{\mathrm{a}}$ compared with the negative control, ${ }^{\mathrm{b}}$ compared with MA $250 \mathrm{mg} / \mathrm{kg},{ }^{\mathrm{c}}$ compared with MA $500 \mathrm{mg} / \mathrm{kg},{ }^{\mathrm{d}}$ compared with MA $1000 \mathrm{mg} / \mathrm{kg}$, and ${ }^{\beta}$ compared with the baseline blood glucose level; ${ }^{\mathrm{E}} \mathrm{P}<0.05,{ }^{\mathrm{F}} \mathrm{P}<0.01,{ }^{\mathrm{G}} \mathrm{P}<0.001$; MA, Myrsine africana leaf extract; NS, normal saline; GLC, glibenclamide.

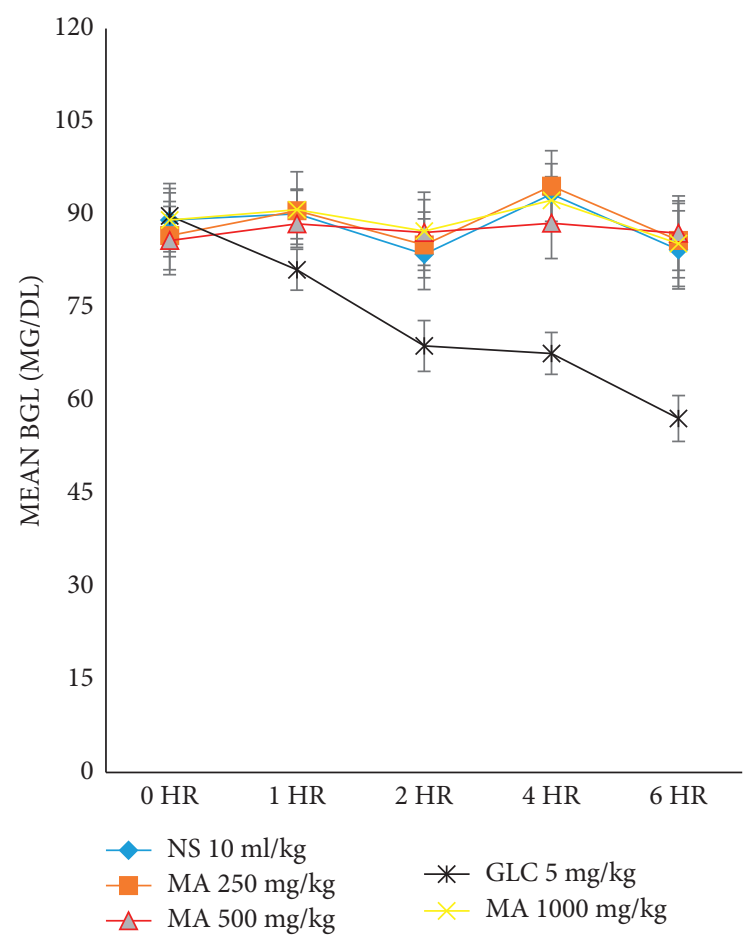

FIGURE 2: The hypoglycemic effects of M. africana leaf extract in normoglycemic mice. MA, Myrsine africana leaf extract; NS, normal saline; GLC, glibenclamide.

TABle 4: Effect of M. africana methanolic leaf extract on oral glucose tolerance in normal mice.

\begin{tabular}{|c|c|c|c|c|}
\hline \multirow{2}{*}{ Group } & \multicolumn{4}{|c|}{ Fasting blood glucose level (mg/kg) } \\
\hline & $0 \mathrm{~min}$ & $30 \mathrm{~min}$ & $60 \mathrm{~min}$ & $120 \mathrm{~min}$ \\
\hline $\mathrm{NS} 10 \mathrm{ml} / \mathrm{kg}$ & $84.8 \pm 3.8$ & $206.6 \pm 10.8^{\beta \mathrm{G}}$ & $160.6 \pm 10.1^{\pi \mathrm{G}}$ & $96.1 \pm 3.6^{\pi \mathrm{G}}$ \\
\hline MA $250 \mathrm{mg} / \mathrm{kg}$ & $85.3 \pm 3.9$ & $204 \pm 12.8^{\beta \mathrm{G}}$ & $146 \pm 7.6^{\pi \mathrm{G}}$ & $98.8 \pm 4.2^{\pi \mathrm{G}}$ \\
\hline MA $500 \mathrm{mg} / \mathrm{kg}$ & $83.3 \pm 4.7$ & $208 \pm 7.5^{\beta \mathrm{G}}$ & $141.6 \pm 11.6^{\pi \mathrm{G} \text { aF }}$ & $106.3 \pm 14^{\pi \mathrm{G}}$ \\
\hline MA $1000 \mathrm{mg} / \mathrm{kg}$ & $83 \pm 5.5$ & $203.1 \pm 9.6^{\beta \mathrm{G}}$ & $132 \pm 6.6^{\pi \mathrm{G} \text { aG }}$ & $98.5 \pm 5.2 \pi \mathrm{G}$ \\
\hline GLC $5 \mathrm{mg} / \mathrm{kg}$ & $83.5 \pm 4.3$ & $206.3 \pm 14.7^{\beta \mathrm{G}}$ & 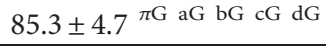 & $75.3 \pm 4.6^{\pi \mathrm{G} \text { aF bG cG dG }}$ \\
\hline
\end{tabular}

Values are expressed as mean $\pm \mathrm{SD} ; n=6$; time refers to the time after oral glucose administration; ${ }^{\mathrm{a}}$ compared with the negative control, ${ }^{\mathrm{b}}$ compared with MA $250 \mathrm{mg} / \mathrm{kg},{ }^{\mathrm{c}}$ compared with MA $500 \mathrm{mg} / \mathrm{kg},{ }^{\mathrm{d}}$ compared with MA $1000 \mathrm{mg} / \mathrm{kg},{ }^{\beta}$ compared with baseline blood glucose level, and ${ }^{\pi}$ compared with the blood glucose level at 30 minutes; ${ }^{\mathrm{F}} P<0.01,{ }_{\mathrm{G}} \mathrm{P}<0.001$; MA, Myrsine africana leaf extract; NS, normal saline; GLC, glibenclamide.

normal control group. On the $7^{\text {th }}$ day, the BGL has shown significant decrement $(P<0.05)$ in MA $500 \mathrm{mg} / \mathrm{kg}$ and MA $1000 \mathrm{mg} / \mathrm{kg}$ groups when compared with the diabetic control group. On the $14^{\text {th }}$ day, the result has revealed that a statistically significant reduction of BGL in all the M. africanatreated groups when compared with the diabetic control group (Figure 5). Besides, on the $7^{\text {th }}$ and $14^{\text {th }}$ days, a significant reduction of BGL was seen in GLC-treated group when compared with the diabetic control group. However, at all time points, the BGL was not statistically different between all $M$. africana-treated and GLC-treated groups. At all time points, the BGL of all the $M$. africana-treated groups 


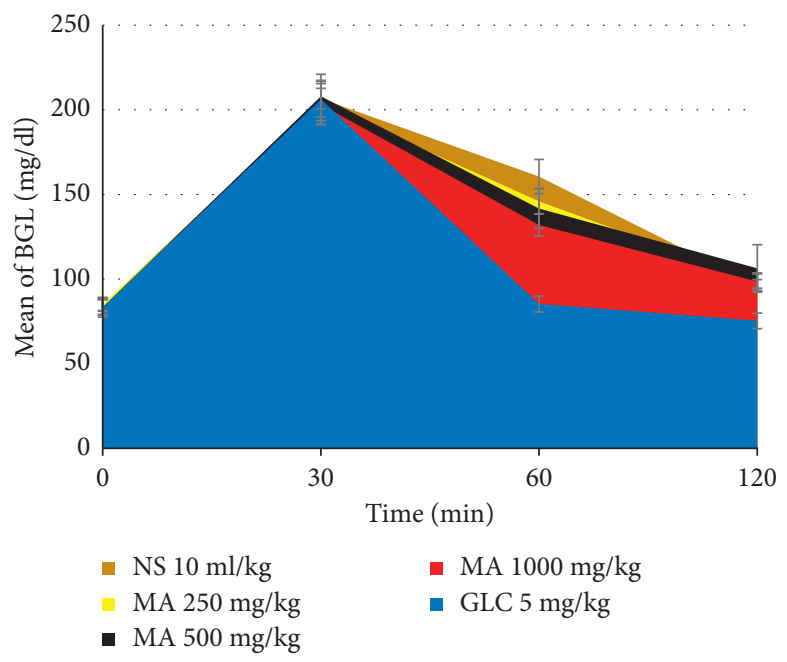

Figure 3: The area curve shows the blood glucose-lowering effect of $M$. africana leaf extract in the oral glucose tolerance test. MA, Myrsine africana leaf extract; NS, normal saline; GLC, glibenclamide.

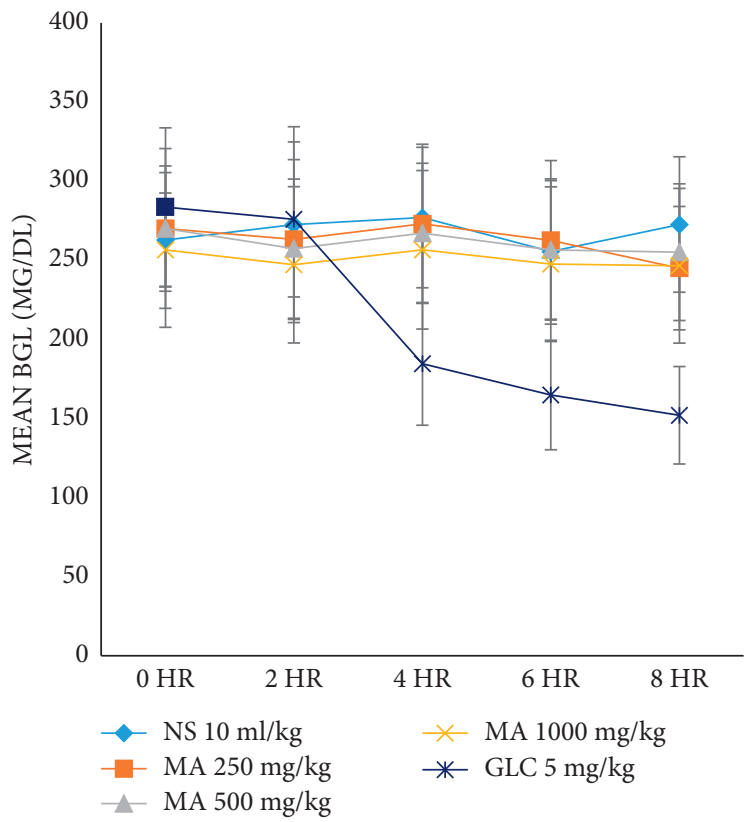

Figure 4: The blood glucose-lowering effect of $M$. africana leaf extract after single-dose administration in diabetic mice. MA, Myrsine africana leaf extract; NS, normal saline; GLC, glibenclamide.

Table 5: Antihyperglycemic activity of a single dose of $M$. africana methanolic leaf extract in diabetic mice.

\begin{tabular}{lccccc}
\hline \multirow{2}{*}{ Group } & \multicolumn{4}{c}{ Fasting blood glucose level (mg) } \\
& $0 \mathrm{hr}$ & $2 \mathrm{hr}$ & $4 \mathrm{hr}$ & $6 \mathrm{hr}$ & $8 \mathrm{hr}$ \\
\hline NS $10 \mathrm{ml} / \mathrm{kg}$ & $262.8 \pm 29.7$ & $272.5 \pm 61.9$ & $277 \pm 44.4$ & $255.5 \pm 45.9$ & $272.6 \pm 42.8$ \\
MA $250 \mathrm{mg} / \mathrm{kg}$ & $270.1 \pm 50.5$ & $263.1 \pm 50.5$ & $273 \pm 50.3$ & $262.6 \pm 50.4$ & $245 \pm 39$ \\
MA $500 \mathrm{mg} / \mathrm{kg}$ & $270 \pm 39.6$ & $257.3 \pm 44$ & $267.1 \pm 44.2$ & $256.5 \pm 43.8$ & $255.1 \pm 43.2$ \\
MA $1000 \mathrm{mg} / \mathrm{kg}$ & $256.5 \pm 48.9$ & $247.1 \pm 49.4$ & $256.6 \pm 50.1$ & $247.5 \pm 48.9$ & $246.5 \pm 48.9$ \\
GLC $5 \mathrm{mg} / \mathrm{kg}$ & $283.6 \pm 50.1$ & $275.8 \pm 49$ & $184.5 \pm 38.8^{\beta \mathrm{G} \mathrm{aE} \mathrm{bE} \mathrm{cE}}$ & $164.8 \pm 34.6^{\beta \mathrm{G} \mathrm{aE} \mathrm{bF} \mathrm{cE} \mathrm{dE}}$ & $152 \pm 30.8^{\beta \mathrm{G} \mathrm{aG} \mathrm{bF} \mathrm{cF} \mathrm{dF}}$ \\
\hline
\end{tabular}

Values are expressed as mean $\pm \mathrm{SD} ; n=6$; ${ }^{\text {a }}$ compared with the negative control, ${ }^{\mathrm{b}}$ compared with MA $250 \mathrm{mg} / \mathrm{kg},{ }^{\mathrm{c}}$ compared with MA $500 \mathrm{mg} / \mathrm{kg},{ }^{\mathrm{d}}$ compared with MA $1000 \mathrm{mg} / \mathrm{kg}$, and ${ }^{\beta}$ compared with baseline blood glucose level; ${ }^{\mathrm{E}} \mathrm{P}<0.05,{ }^{\mathrm{F}} \mathrm{P}<0.01,{ }^{\mathrm{G}} \mathrm{P}<0.001$; MA, Myrsine africana leaf extract; NS, normal saline; GLC, glibenclamide. 
TABle 6: Antihyperglycemic activity of repeated daily dose of $M$. africana methanolic leaf extract in diabetic mice.

\begin{tabular}{lccc}
\hline \multirow{2}{*}{ Group } & \multicolumn{3}{c}{ Fasting blood glucose level (mg/dl) } \\
\hline Diabetic control & Baseline & $7^{\text {th }}$ day & $14^{\text {th }}$ day \\
MA $250 \mathrm{mg} / \mathrm{kg}$ & $262.8 \pm 29.7^{\mathrm{nG}}$ & $234.1 \pm 28.8$ & $226.8 \pm 31.9$ \\
MA $500 \mathrm{mg} / \mathrm{kg}$ & $270.1 \pm 50.5^{\mathrm{nG}}$ & $199.8 \pm 42.3^{\beta \mathrm{G}}$ & $172.1 \pm 13^{\beta \mathrm{G} \alpha \mathrm{F}}$ \\
MA $1000 \mathrm{mg} / \mathrm{kg}$ & $270 \pm 39.6^{\mathrm{nG}}$ & $179.6 \pm 17.4^{\beta \mathrm{G} \alpha \mathrm{E}}$ & $167.6 \pm 13.7^{\beta \mathrm{G} \alpha \mathrm{G}}$ \\
GLC $5 \mathrm{mg} / \mathrm{kg}$ & $256.5 \pm 48.9^{\mathrm{nG}}$ & $167.1 \pm 9.3^{\beta \mathrm{G} \alpha \mathrm{E}}$ & $159.3 \pm 6.9^{\beta \mathrm{G} \alpha \mathrm{G}}$ \\
Normal control & $283.6 \pm 50.1^{\mathrm{nG}}$ & $165.1 \pm 21.3^{\beta \mathrm{G} \alpha \mathrm{F}}$ & $140.5 \pm 32.5^{\beta \mathrm{G} \alpha \mathrm{G}}$ \\
\hline
\end{tabular}

Values are expressed as mean $\pm \mathrm{SD} ; n=6 ;{ }^{\alpha}$ compared with diabetic control, ${ }^{n}$ compared with normal control, ${ }^{\beta}$ compared with baseline blood glucose level; ${ }^{\mathrm{E}}$ $P<0.05,{ }^{\mathrm{F}} P<0.01,{ }^{\mathrm{G}} P<0.001$; MA, Myrsine africana leaf extract; NS, normal saline; GLC, glibenclamide.

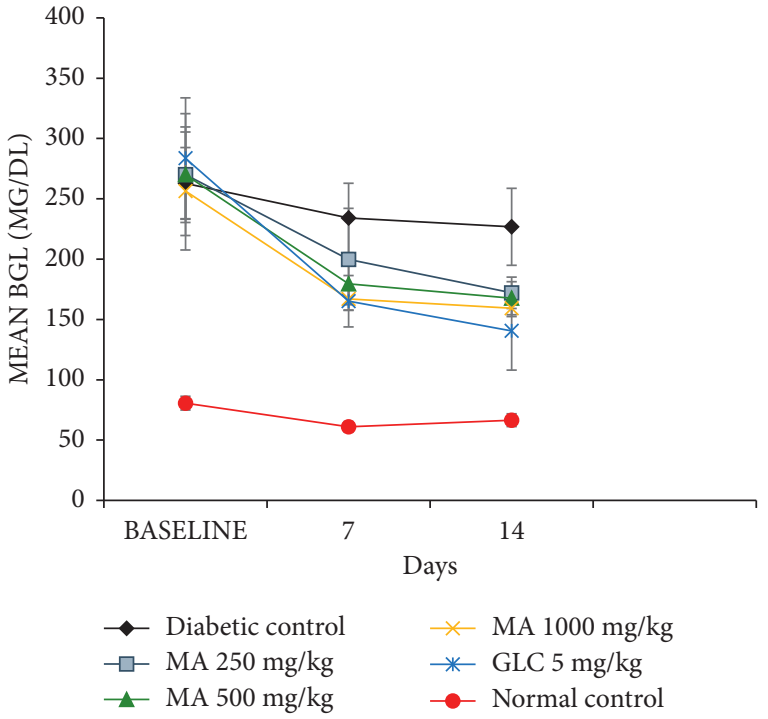

Figure 5: The blood glucose-lowering effect of $M$. africana leaf extract after repeated daily dose administration in diabetic mice. MA, Myrsine africana leaf extract; GLC, glibenclamide.

did not show statistical differences when compared with each other. At the $7^{\text {th }}$ and $14^{\text {th }}$ days, the BGL has shown a significant reduction $(P<0.001)$ when compared with its baseline level in both GLC-treated and M. africana-treated groups.

\subsection{Effect of Repeated Daily Dose of M. africana Methanolic} Leaf Extract on Body Weight in Diabetic Mice. As indicated in Table 7 , at the $7^{\text {th }}$ and $14^{\text {th }}$ days, the weight of animals in the diabetic control group has significantly dropped $(P<0.001)$ when compared with the normal control group. On the 7th day, there was a significant $(P<0.05)$ weight gain in the MA $1000 \mathrm{mg} / \mathrm{kg}$ group compared with the diabetic control group. In addition, on the $14^{\text {th }}$ day, a significant weight improvement was seen in all the M. africana-treated groups compared with the diabetic control group. At the $7^{\text {th }}$ and $14^{\text {th }}$ days, the weight of mice was significantly reduced in both MA $250 \mathrm{mg} / \mathrm{kg}$ and MA $500 \mathrm{mg} / \mathrm{kg}$ groups compared with the normal control group. In the GLC-treated group, a significant $(P<0.001)$ weight improvement was seen when compared with the diabetic control group at the $7^{\text {th }}$ and $14^{\text {th }}$ days.
3.10. Effect of Repeated Daily Dose of M. africana Methanolic Leaf Extract on the Serum Lipid Level in Diabetic Mice. In the diabetic control group when compared with the normal control group, the levels of total cholesterol (TC) and triglycerides (TGs) increased significantly $(P<0.001)$; and high-density lipoprotein (HDL) cholesterol was significantly decreased $(P<0.001)$ (Table 8, Figure 6). After 14 days of treatment, when $M$. africana-treated groups compared with diabetic control, the TC and TG levels were decreased, while the HDL level increased significantly. Likewise, in comparing the GLC-treated group with diabetic control, a significant reduction of TG and TC and a significant increment of HDL were seen in the GLC-treated group $(P<0.001)$. The levels of TC, TG, and HDL-C did not show a statistically significant difference in all the $M$. africana-treated groups when compared with each other. In the GLC-treated group, the state of dyslipidemia was corrected better when compared with all the M. africana-treated groups.

3.11. Effect of M. africana on Insulin and Hexokinase. The insulin level was significantly decreased in the diabetic control group compared with the normal control group, whereas the insulin level was significantly elevated $(P<0.001)$ in all the M. africana-treated groups compared with the diabetic control group. A more prominent increment of insulin level was seen in the MA $1000 \mathrm{mg} / \mathrm{kg}$ group when compared with other $M$. africana-treated groups (Figure 7, Table 9).

Likewise, the hexokinase level was significantly increased in all the $M$. africana-treated and GLC-treated groups compared with the diabetic control group. In M. africanatreated groups, the increment of hexokinase was dose dependent (Figure 7 and Table 9).

3.12. Effect of M. africana on Glycated Hemoglobin, Glucose6-Phosphatase, and Fructose-1-6-Bisphosphatase. The glycated hemoglobin was significantly increased in the diabetic control group. Conversely, a significantly decreased level of glycated hemoglobin was seen in all the M. africana-treated and GLC-treated groups when compared with the diabetic control group. The effect of $M$. africana on glycated hemoglobin was dose dependent (Figure 8 and Table 9).

The levels of glucose-6-phosphatase and fructose-1-6bisphosphatase were significantly decreased in all the $M$. africana-treated and GLC-treated groups when 
TABLE 7: Effect of the repeated daily dose of M. africana methanolic leaf extract on body weight in diabetic mice.

\begin{tabular}{lcccc}
\hline \multirow{2}{*}{ Group } & & \multicolumn{2}{c}{ Body weight (gm.) } \\
& Before diabetes induction & Baseline & $7^{\text {th }}$ day of treatment & $14^{\text {th }}$ day of treatment \\
\hline Diabetic control & $24.3 \pm 4.1$ & $19.3 \pm 4$ & $19.6 \pm 3.2^{\mathrm{nG}}$ & $15 \pm 2.8^{\beta \mathrm{F} \mathrm{nG}}$ \\
MA $250 \mathrm{mg} / \mathrm{kg}$ & $23 \pm 3.2$ & $18.3 \pm 1.8$ & $23 \pm 1.2^{\mathrm{nE}}$ & $19.6 \pm 2.4^{\mathrm{nG} \alpha \mathrm{E}}$ \\
MA $500 \mathrm{mg} / \mathrm{kg}$ & $25 \pm 1.5$ & $19.3 \pm 3$ & $21.6 \pm 2.4^{\mathrm{nF}}$ & $22.3 \pm 2.5^{\mathrm{nE} \alpha \mathrm{G}}$ \\
MA $1000 \mathrm{mg} / \mathrm{kg}$ & $23 \pm 3.2$ & $18.3 \pm 2.8$ & $24.3 \pm 2.5^{\alpha \mathrm{E}}$ & $22.6 \pm 2^{\alpha \mathrm{G}}$ \\
GLC $5 \mathrm{mg} / \mathrm{kg}$ & $25 \pm 3.5$ & $19.3 \pm 2$ & $27.6 \pm 1.8^{\alpha \mathrm{G}}$ & $26.8 \pm 1.4^{\alpha \mathrm{G}}$ \\
Normal control & $23 \pm 2.2$ & $21.6 \pm 2.1$ & $28 \pm 1.8$ & $26.8 \pm 2.1$ \\
\hline
\end{tabular}

Values are expressed as mean $\pm \mathrm{SD} ; n=6{ }^{\alpha}{ }^{\alpha}$ compared with diabetic control, ${ }^{n}$ compared with normal control, ${ }^{\beta}$ compared with baseline blood glucose level; ${ }^{\mathrm{E}}$ $P<0.05,{ }^{\mathrm{F}} P<0.011,{ }^{\mathrm{G}} \mathrm{P}<0.001$; MA, Myrsine africana leaf extract; NS, normal saline; GLC, glibenclamide.

TABLE 8: Effect of the repeated daily dose of $M$. africana methanolic leaf extract on the serum lipid level in diabetic mice.

\begin{tabular}{|c|c|c|c|}
\hline \multirow{2}{*}{ Group } & \multicolumn{3}{|c|}{ Serum lipid level (mg/dl) } \\
\hline & HDL-C & TC & TG \\
\hline Diabetic control & $19.6 \pm 2.1^{\mathrm{nG}}$ & $177.3 \pm 3.3^{\mathrm{nG}}$ & $142.8 \pm 7.1^{\mathrm{nG}}$ \\
\hline MA $250 \mathrm{mg} / \mathrm{kg}$ & $25.5 \pm 1.8^{\text {nG } \alpha \mathrm{E}}$ & $153.6 \pm 2.1 \mathrm{nG} \alpha \mathrm{G}$ & $135.1 \pm 4.4 \mathrm{nG}$ \\
\hline MA $500 \mathrm{mg} / \mathrm{kg}$ & $26.5 \pm 1.8^{\mathrm{nG} \alpha \mathrm{E}}$ & $157.5 \pm 13^{\mathrm{nG} \alpha \mathrm{G}}$ & $133.6 \pm 3.5^{\mathrm{nG} \alpha \mathrm{E}}$ \\
\hline $\mathrm{MA} 1000 \mathrm{mg} / \mathrm{kg}$ & $28.8 \pm 2.4^{\mathrm{nG} \alpha \mathrm{G}}$ & $153 \pm 4^{\mathrm{nG} \alpha \mathrm{G}}$ & $130.1 \pm 2.8^{\mathrm{nG} \alpha \mathrm{F}}$ \\
\hline GLC $5 \mathrm{mg} / \mathrm{kg}$ & $36.6 \pm 5 \alpha \mathrm{G} \mathrm{bF} \mathrm{cF} \mathrm{dF}$ & $83 \pm 2^{\alpha \mathrm{G} \text { bF cF dF }}$ & $57.5 \pm 4.5^{\alpha \mathrm{G} \mathrm{bF} \mathrm{cF} \mathrm{dF}}$ \\
\hline Normal control & $38.1 \pm 3.1$ & $70.3 \pm 3.7$ & $53.3 \pm 3.7$ \\
\hline
\end{tabular}

Values are expressed as mean $\pm \mathrm{SD} ; n=6 ;{ }^{\alpha}$ compared with diabetic control, ${ }^{\mathrm{b}}$ compared with MA $250 \mathrm{mg} / \mathrm{kg},{ }^{\mathrm{c}}$ compared with MA $500 \mathrm{mg} / \mathrm{kg},{ }^{\mathrm{d}}$ compared with MA $1000 \mathrm{mg} / \mathrm{kg}$, and ${ }^{\mathrm{n}}$ compared with normal control; ${ }^{\mathrm{E}} P<0.05,{ }^{\mathrm{F}} P<0.01,{ }^{\mathrm{G}} P<0.001 ; \mathrm{MA}$, Myrsine africana leaf extract; GLC, glibenclamide; TC, total cholesterol; TG, triglyceride; HDL-C, high-density lipoprotein cholesterol.

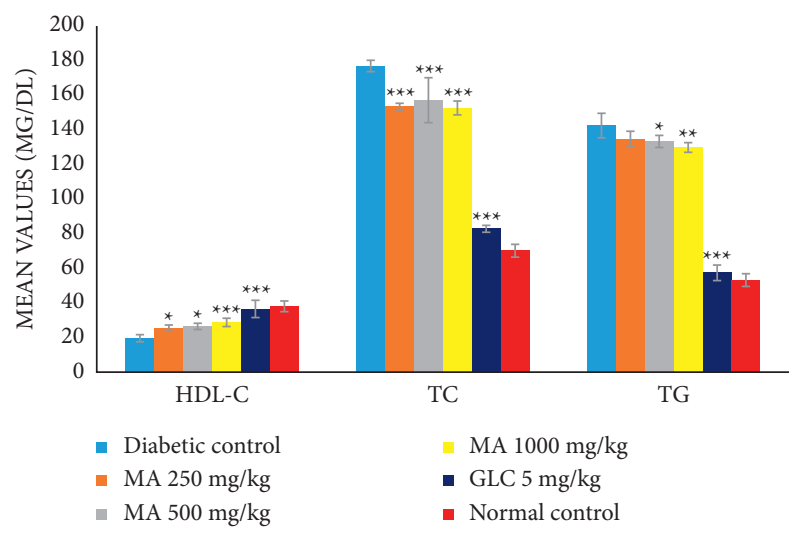

FIGURE 6: Trends of the effects of $M$. africana methanolic leaf extract on serum lipid profiles of diabetic mice. ${ }^{*} P<0.05,{ }^{* *} P<0.01$, and ${ }^{* * *} P<0.001$ considered significant when compared with the diabetic control group. GLC, glibenclamide; MA, Myrsine africana leaf extract; HDL-C, high-density lipoprotein cholesterol; TC, total cholesterol; TG, triglyceride.

compared with the diabetic control group (Figure 8 and Table 9).

\section{Discussion}

DM is the known metabolic disease described by elevated blood glucose levels due to compromised metabolism of macromolecules such as carbohydrates, lipids, and proteins and related to absolute or relative deficiencies in insulin secretion or/and insulin action [41]. The need for safe and efficient antidiabetic drugs is still the world scientific community issue. Exploring new modern medications from

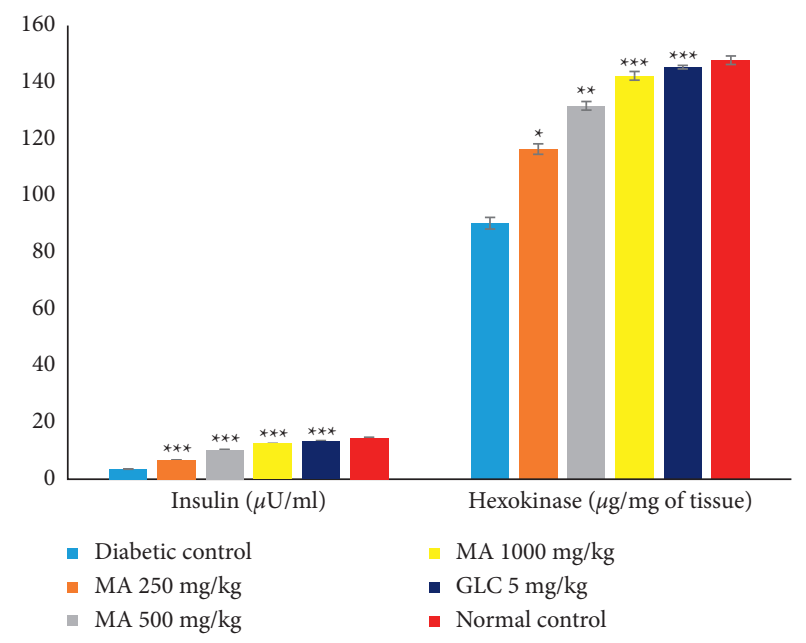

Figure 7: The effects of $M$. africana leaf extract on insulin and hexokinase levels in diabetic mice. ${ }^{*} P<0.05,{ }^{* *} P<0.01$, and ${ }^{* * *} P<0.001$ considered significant when compared with the diabetic control group. MA, Myrsine africana leaf extract; GLC, glibenclamide.

traditional medicinal plants is an important research area, which does not require advanced pharmaceutical settings and provides easier accessibility $[9,34]$.

The current study revealed that the methanolic extract from $M$. africana leaves can potentially treat diabetes mellitus. Acute oral toxicity test results of $M$. africana showed that the extract seems nontoxic $\left(\mathrm{LD}_{50}>5000 \mathrm{mg} / \mathrm{kg}\right)$. The extract has a significant effect on decreasing blood glucose levels in diabetes-induced albino mice. The extract also showed the ability to increase the protective HDL level and 
TABLE 9: Effect of M. africana methanolic leaf extract on glycated hemoglobin, insulin, and carbohydrate metabolizing enzymes in diabetic mice.

\begin{tabular}{|c|c|c|c|c|c|}
\hline \multirow[b]{2}{*}{ Groups } & \multicolumn{5}{|c|}{ Biochemical parameters } \\
\hline & HbAlc (\%) & Insulin $(\mu \mathrm{U} / \mathrm{ml})$ & $\begin{array}{c}\text { Hexokinase } \\
(\mu \mathrm{g} / \mathrm{mg} \text { of tissue })\end{array}$ & $\begin{array}{l}\text { Glucose-6-phosphatase } \\
\text { (unit/mg of tissue) }\end{array}$ & $\begin{array}{l}\text { Fructose-1-6-bisphosphatase } \\
\text { (unit/mg of tissue) }\end{array}$ \\
\hline Diabetic control & $4.8 \pm 0.18^{\pi * * *}$ & $3.6 \pm 0.06^{\pi * * *}$ & $90.58 \pm 2.06^{\pi * * *}$ & $14.2 \pm 0.23^{\pi * * *}$ & $55.38 \pm 0.27^{\pi * * *}$ \\
\hline MA $250 \mathrm{mg} / \mathrm{kg}$ & $3.5 \pm 0.09^{\boldsymbol{\alpha}_{* *}}$ & $6.8 \pm 0.05^{\alpha * * *}$ & $116.82 \pm 1.85^{\boldsymbol{\alpha}_{*}}$ & $13.7 \pm 0.36^{\boldsymbol{\alpha}_{*}}$ & $43.5 \pm 0.43^{\boldsymbol{\alpha}_{* *}}$ \\
\hline MA $500 \mathrm{mg} / \mathrm{kg}$ & $2.9 \pm 0.05^{\alpha_{* *}}$ & $10.4 \pm 0.17^{\boldsymbol{\alpha}_{* * *}}$ & $132.12 \pm 1.52^{\boldsymbol{\alpha}_{* *}}$ & $11.5 \pm 0.19^{\alpha_{* *}}$ & $38.34 \pm 0.52^{\boldsymbol{\alpha}_{* * *}}$ \\
\hline MA $1000 \mathrm{mg} / \mathrm{kg}$ & $2 \pm 0.02^{\boldsymbol{\alpha} * * *}$ & $12.6 \pm 0.09^{\boldsymbol{\alpha} * * *}$ & $142.73 \pm 1.54^{\alpha * * *}$ & $9.8 \pm 0.03^{\alpha * * *}$ & $31.94 \pm 0.48^{\boldsymbol{\alpha} * * *}$ \\
\hline GLC $5 \mathrm{mg} / \mathrm{kg}$ & $2.1 \pm 0.06^{\boldsymbol{\alpha}_{* * *}}$ & $13.4 \pm 0.27^{\boldsymbol{\alpha}_{* * *}}$ & $145.79 \pm 0.63^{\alpha * * *}$ & $8.6 \pm 0.14^{\alpha * * *}$ & $30.55 \pm 0.8^{\boldsymbol{\alpha}_{* * *}}$ \\
\hline Normal control & $1.2 \pm 0.15$ & $14.6 \pm 0.25$ & $148.25 \pm 1.51$ & $9 \pm 0.15$ & $28.39 \pm 0.55$ \\
\hline
\end{tabular}

Values are expressed as mean $\pm \mathrm{SD} ; n=6 ;{ }^{\pi}$ compared with normal control; ${ }^{\alpha}$ compared with diabetic control; ${ }^{*} P<0.05,{ }^{* *} P<0.01,{ }^{* * *} P<0.001 ; \mathrm{HbA} 1 \mathrm{c}$, glycated hemoglobin; MA, Myrsine africana leaf extract.

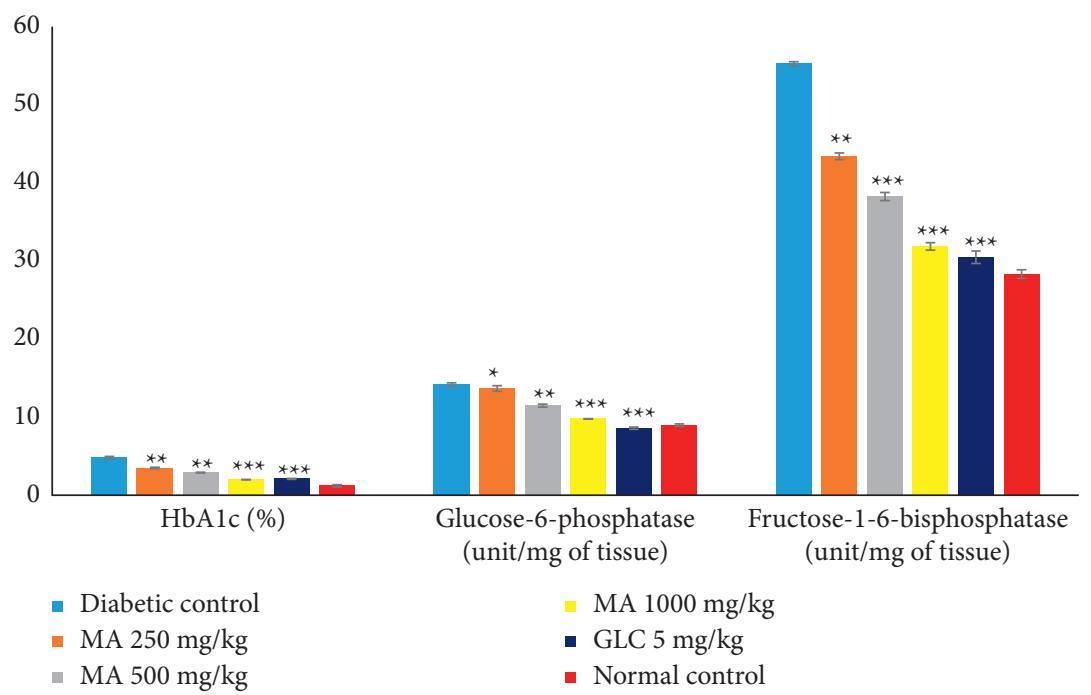

Figure 8: The effects of M. africana leaf extract on glycated hemoglobin, glucose-6-phosphatase, and fructose-1-6-bisphosphatase levels in diabetic mice. ${ }^{*} P<0.05,{ }^{* *} P<0.01$, and ${ }^{* * *} P<0.001$ considered significant when compared with the diabetic control group. HbA1c, glycated hemoglobin; MA, Myrsine africana leaf extract; GLC, glibenclamide.

reduce the unwanted lipid profiles. Moreover, M. africana has increased the insulin and hexokinase levels in diabetic mice, while it decreased the levels of glucose-6-phosphatase and fructose-1-6-bisphosphatase. Also, M. africana leaf extract might contribute to improved weight gains in diabetic mice.

Based on the results of this study, the $\mathrm{LD}_{50}$ of the methanolic leaf extract of $M$. africana is found to be more than $5000 \mathrm{mg} / \mathrm{kg}$. In another study, the acute toxicity study of $M$. africana seed extract had shown the $\mathrm{LD}_{50}$ more than $5000 \mathrm{mg} / \mathrm{kg}$ [17].

Alloxan is a commonly used chemical for the induction of diabetes in rodents $[42,43]$. This study has revealed the successful induction of diabetes in mice using alloxan compound. In another previous study as well, alloxan has induced persistent hyperglycemia in mice [26]. Likewise, in this study, sustained alloxan-induced hyperglycemia has been observed for a two-week study period as indicated in the diabetic control group (Table 6). After alloxan exposure, there will be pancreatic $\beta$ cell malfunctioning due to DNA fragmentation and damage, production of superoxide radicals, and generation of reactive oxygen species [43].
The effect of the extract on normoglycemic animals suggests that the leaf of $M$. africana has a mild lowering effect on normal glucose levels (Table 3). This effect was comparable to that of glibenclamide, an insulin secretagogue, which also lowers blood glucose in normal animals. Provided the $\beta$-cells are fully functional, sulphonylureas, such as glibenclamide, can cause hypoglycemia since insulin release is initiated even when glucose concentration is below the normal threshold due to glucose-stimulated insulin release $[32,41,44]$.

An oral glucose tolerance test is used to identify the altered carbohydrate metabolism during post-glucose administration. The ability of methanolic extract of M. africana leaf to lower the blood glucose level in oral glucose tolerance test suggests that mice treated with the doses of MA $1000 \mathrm{mg} / \mathrm{kg}$ and MA $500 \mathrm{mg} / \mathrm{kg}$ had better glucose utilization capacity. The reasons might be due to insulin emission from $\beta$-cells thereby that improved glucose transport and consumption [41].

The methanolic extract of $M$. africana leaf improved the blood glucose level in alloxan-induced diabetic mice. The M. africana dose $1000 \mathrm{mg} / \mathrm{kg}$ was most effective to reduce 
the raised blood glucose level (Table 6). The possible mechanism of activity of $M$. africana leaf extract may be stimulating the insulin secretion and regeneration of the $\beta$-cells of the pancreas or increasing cellularity of the islet tissue and regeneration of the granules in the $\beta$-cells. According to this result, it can be hypothesized that $M$. africana declined the level of blood glucose and improved the insulin level $[26,44]$, but further molecular studies are recommended to ascertain the actual mechanism for the antihyperglycemic effects noticed in this study.

There are strong experimental pieces of evidence that show that patients with diabetes mellitus are susceptible to an increase in the blood level of oxidants. In most medicinal plants, the presence of phytochemicals such as alkaloids, phenolic compounds, flavonoids, and terpenoids is responsible for their antidiabetic activity [8-13]. In recent years, much of the research interest was on the antioxidant activity of flavonoids due to their ability to reduce the formation and to scavenge the free radicals. Besides, the flavonoids have $\beta$-cell regenerating and insulinogenic effects $[10,11]$. In this study also, the methanolic extract of $M$. africana has shown better antioxidant activity (Figure 1). Therefore, the presence of such phytonutrients in $M$. africana might contribute to the lowering of blood glucose levels [7, 17].

A diabetic state is characterized by severe loss in body weight because of loss or degradation of structural proteins. Due to insulin deficiency, there will be a marked reduction in the protein content in the muscular tissue via proteolysis [45]. This study also showed a significant body weight reduction in the diabetic mice group (Table 7), whereas the body weight was restored in M. africana-treated groups. The rebuilding of the weight loss in $M$. africana-treated groups may be due to cessation of proteolysis, gluconeogenesis, and glycogenolysis. Diabetes mellitus is associated with an increased rate of glycogenolysis, lipolysis, proteolysis, and gluconeogenesis [46]. The weight gain seen after repeated administration of $M$. africana might indicate its antihyperglycemic effect.

In the pathogenesis of diabetes, lipid plays a significant role. Increased levels of cholesterol and lipids in plasma represent a risk factor for coronary artery disease [46, 47]. Insulin deficiency causes activation of hormone-sensitive lipase that can lead to increased lipolysis and increased secretion of VLDL from the liver $[47,48]$. Decreased activity of lipoprotein lipase, secondary to insulin deficiency, also leads to decreased clearance of chylomicrons and VLDL [49]. In addition, hypertriglyceridemia stimulates the enzymatic action of cholesterol ester transfer protein, which leads to an increase in the triglyceride content of LDL and HDL. Triglyceride-enriched HDL particles easily undergo catabolism, and triglyceride-enriched LDL particles undergo subsequent hydrolysis via hepatic lipase or lipoprotein lipase, resulting in reduced LDL particle size [47].

This study revealed a significant increment of serum TG and TC and a remarkable decrement of HDL-C in diabetic mice (Figure 6 and Table 8). Treating alloxan-induced diabetic groups with glibenclamide and different doses of M. africana leaf extract reduced the total cholesterol and triglyceride level to a significant extent in a dose-dependent manner, while it increased the beneficial HDL level to a substantial amount. The mechanism of the antidyslipidemic effect of $M$. africana is indirectly through controlled hyperglycemia or directly by influencing lipid metabolism.

In this study, the insulin level was decreased in the alloxan-induced diabetic mice. Different doses of $M$. africana leaf extract increased the insulin level, which may be due to active ingredients available in the plant extract. $M$. africana leaf extract may induce insulin secretion or maintain the function of $\beta$-cells from further damage, thereby keeping them active to produce insulin. Oral administration of the M. africana leaf extract for 14 days significantly decreased the blood glucose level with increasing insulin level. The mechanism of action of the plant extract might be by potentiating insulin secretion from $\beta$-cells, evidenced by this study that a significant elevation of insulin level was seen (Figure 7).

The glycated hemoglobin level was increased in alloxaninduced diabetic animals due to excessive glucose production in the blood, which further reacts with blood hemoglobin and prepared more glycated hemoglobin [50]. In this study, all doses of $M$. africana extract significantly lowered blood glucose and consequently decreased glycated hemoglobin levels. The possible mechanism of action might be due to having direct proportionality between blood glucose level and glycated hemoglobin. When the blood glucose level drops, the glycated hemoglobin will also decrease and vice versa.

The liver is a vital organ and plays an important role in defending the postprandial hyperglycemia and synthesis of glucose metabolism. The main role of the liver in glucose utilization is to convert the glucose into glucose-6-phosphate with the help of hexokinase, and another role is it converts glucose into energy [51, 52]. Alloxan-induced diabetic groups showed an increase in the level of glucose-6-phosphatase, which increased the production of fats to carbohydrates that deposited into the liver and kidneys and thus altered the level of hexokinase, which decreased the conversion and utilization of glucose. Another effect of diabetes is an increased level of fructose-1-6-bisphosphatase [52]. Treating alloxan-induced diabetic groups with different doses of M. africana leaf extract and glibenclamide increased the level of hexokinase and decreased the levels of glucose-6phosphatase and fructose-1-6-bisphosphatase and brought the levels closer to the levels of normal control.

\section{Conclusion}

Thus, this study revealed that $M$. africana leaf extract has antidiabetic and antidyslipidemic effects, evidenced by decreased levels of blood glucose, glycated hemoglobin, glucose-6-phosphatase, fructose-1-6-bisphosphatase, total cholesterol, and triglyceride and increased levels of HDLcholesterol, hexokinase, and insulin. The plant extract has also shown better glucose utilization in oral glucose tolerance tests and body weight improvements in diabetic mice. Further molecular studies are recommended to identify and understand the mechanisms of action of different compounds found in the plant. 


\section{Abbreviations}

ANOVA: Analysis of variance

BGL: $\quad$ Blood glucose level

DM: $\quad$ Diabetes mellitus

GLC: Glibenclamide

HDL: High-density lipoprotein

HDL-C: High-density lipoprotein cholesterol

IDF: International Diabetes Federation

IP: Intraperitoneal

$\mathrm{LD}_{50}$ : Median lethal dose

NS: $\quad$ Normal saline

OECD: Organization for Economic Cooperation and Development

MA: $\quad$ Myrsine africana

SD: $\quad$ Standard deviation

SPSS: $\quad$ Statistical Software Package for Social Science

TC: Total cholesterol

TG: $\quad$ Triglyceride

VLDL: Very low-density lipoprotein.

\section{Data Availability}

The data used to support the findings of this study are available from the corresponding author upon request.

\section{Ethical Approval}

Ethical approval was obtained from the Debre Berhan University Institutional Review Board Committee members (Dr. Esubalaew Tesfahun, Dr. Amare Ayalew, and Dr. Gezahegn Degafe) with the protocol number P004. The experiment was carried out based on the guideline for the care and use of laboratory animals [53].

\section{Disclosure}

The university had no role in the study design, analysis, and data interpretation.

\section{Conflicts of Interest}

The author declares no conflicts of interest.

\section{Authors' Contributions}

YE made substantial contributions to conception and design, acquisition of data, and analysis and interpretation of data; took part in drafting the article and revising it critically for important intellectual content; agreed on the journal to which the article will be submitted; gave final approval of the version to be published; and agreed to be accountable for all aspects of the work.

\section{Acknowledgments}

The author expressed thanks to Debre Berhan University, Ethiopia, for funding this study. This fund was provided for purchasing lab instruments and reagents. Agerie Yigezu was recognized for assisting in the laboratory work. Dr. Abiyou
Tilahun and Dr. Minbale Gashu were acknowledged for their support in the plant identification and extraction process.

\section{References}

[1] S. Stephen Irudayaraj, C. Sunil, V. Duraipandiyan, and S. Ignacimuthu, "Antidiabetic and antioxidant activities of Toddalia asiatica (L.) Lam. leaves in Streptozotocin induced diabetic rats," Journal of Ethnopharmacology, vol. 143, no. 2, pp. 515-523, 2012.

[2] V. Hall, R. W. Thomsen, O. Henriksen, and N. Lohse, "Diabetes in Sub Saharan Africa 1999-2011: epidemiology and public health implications. A systematic review," BMC Public Health, vol. 11, no. 1, p. 564, 2011.

[3] I. D. Federation, IDF Diabetes Atlas, IDF, Tel Aviv, Kirya, Ninth edition, 2019.

[4] S. Ignacimuthu, M. Ayyanar, and S. Sivaraman K, "Ethnobotanical investigations among tribes in Madurai district of Tamil Nadu (India)," Journal of Ethnobiology and Ethnomedicine, vol. 2, no. 1, p. 25, 2006.

[5] W. L. Li, H. C. Zheng, J. Bukuru, and N. De Kimpe, "Natural medicines used in the traditional Chinese medical system for therapy of diabetes mellitus," Journal of Ethnopharmacology, vol. 92, no. 1, pp. 1-21, 2004.

[6] C. J. Bailey, "Metformin: historical overview," Diabetologia, vol. 60, no. 9, pp. 1566-1576, 2017.

[7] S. Laraib, S. Sharif, Y. Bibi, S. Nisa, R. Aziz, and A. Qayyum, "Phytochemical analysis and some bioactivities of leaves and fruits of myrsine africana linn," Arabian Journal for Science and Engineering, vol. 46, no. 1, pp. 53-63, 2020.

[8] J. O. Unuofin and S. L. Lebelo, "Antioxidant effects and mechanisms of medicinal plants and their bioactive compounds for the prevention and treatment of type 2 diabetes: an updated review," Oxidative Medicine and Cellular Longevity, vol. 2020, Article ID 1356893, 13 pages, 2020.

[9] M. U. Rao, M. Sreenivasulu, B. Chengaiah, K. J. Reddy, and C. M. Chetty, "Herbal medicines for diabetes mellitus: a review," Int J PharmTech Res, vol. 2, no. 3, pp. 1883-1892, 2010.

[10] D. Patel, S. Prasad, R. Kumar, and S. Hemalatha, "An overview on antidiabetic medicinal plants having insulin mimetic property," Asian Pacific journal of tropical biomedicine, vol. 2, no. 4, pp. 320-330, 2012.

[11] M. Jung, M. Park, H. Lee, Y.-H. Kang, E. Kang, and S. Kim, "Antidiabetic agents from medicinal plants," Current $\mathrm{Me}$ dicinal Chemistry, vol. 13, no. 10, pp. 1203-1218, 2006.

[12] S. P. Subramanian and G. S. Prasath, "Antidiabetic and antidyslipidemic nature of trigonelline, a major alkaloid of fenugreek seeds studied in high-fat-fed and low-dose streptozotocin-induced experimental diabetic rats," Biomedicine \& Preventive Nutrition, vol. 4, no. 4, pp. 475-480, 2014.

[13] A. K. Verma, H. Singh, M. Satyanarayana et al., "Flavonebased novel antidiabetic and antidyslipidemic agents," Journal of Medicinal Chemistry, vol. 55, no. 10, pp. 4551-4567, 2012.

[14] F. A. Matough, S. B. Budin, Z. A. Hamid, N. Alwahaibi, and J. Mohamed, "The role of oxidative stress and antioxidants in

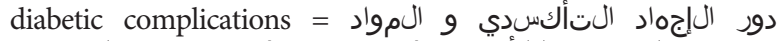

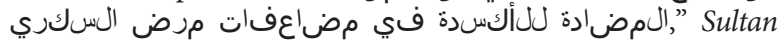
Qaboos University Medical Journal, vol. 12, no. 1, pp. 5-18, 2012.

[15] U. Asmat, K. Abad, and K. Ismail, "Diabetes mellitus and oxidative stress-A concise review," Saudi Pharmaceutical Journal, vol. 24, no. 5, pp. 547-553, 2016.

[16] R. P. Robertson, "Chronic oxidative stress as a central mechanism for glucose toxicity in pancreatic islet beta cells in 
diabetes," Journal of Biological Chemistry, vol. 279, no. 41, pp. 42351-42354, 2004.

[17] Z. N. Kabubii, J. Mbaria, and M. Mathiu, "Acute toxicity studies of Myrsine africana aqueous seed extract in male Wistar rats on some hematological and biochemical parameters," Clinical Phytoscience, vol. 1, no. 1, 2015.

[18] H. Gul, M. Ahmad, M. Zafar et al., "The in vitro and in vivo biological activities of the leaf of Cape Myrtle, myrsine africana L," Phytotherapy Research, vol. 31, no. 9, pp. 1305-1309, 2017.

[19] P. K. Maurya and K. Dua, Eds., Role of Oxidative Stress in Pathophysiology of Diseases, Springer, Berlin, Germany, 2020.

[20] Y.-P. Zou, C.-H. Tan, B.-D. Wang, D.-Y. Zhu, and S.-K. Kim, "Chemical constituents fromMyrsine africanaL," Helvetica Chimica Acta, vol. 91, no. 11, pp. 2168-2173, 2008.

[21] B. Ahmad, S. Azam, S. Bashir, I. Khan, N. Ali, and M. I. Chaudhary, "Phytotoxic, Antibacterial and Haemagglutination activities of the aerial parts of Myrsine africana L," African Journal of Biotechnology, vol. 10, no. 1, pp. 97-102, 2011.

[22] W. C. Evans, Trease and Evans' Pharmacognosy E-Book, Elsevier Health Sciences, Amsterdam, Netherlands, 2009.

[23] A. Pandey and S. Tripathi, "Concept of standardization, extraction and pre phytochemical screening strategies for herbal drug," Journal of Pharmacognosy and Phytochemistry, vol. 2, p. 5, 2014

[24] P. Tiwari, "Phytochemical screening and extraction: a review: intern," Pharmaceutica Sciencia, vol. 1, p. 1, 2011.

[25] Cooperation of E Development, Test No. 425: Acute Oral Toxicity: Up-And-Down Procedure, OECD Publishing, Paris, France, 2008.

[26] T. Dinku, S. Tadesse, and K. Asres, "Antidiabetic activity of the leaf extracts of Pentas schimperiana subsp. schimperiana (A. Rich) Vatke on alloxan induced diabetic mice," Ethiopian Pharmaceutical Journal, vol. 28, pp. 22-26, 2010.

[27] O. M. Ighodaro, A. M. Adeosun, F. O. Asejeje, G. O. Soetan, and O. O. Kassim, "Time course effects of 5,5-dihydroxyl pyrimidine-2,4,6-trione (alloxan) as a diabetogenic agent in animal model," Alexandria journal of medicine, vol. 54, no. 4, pp. 705-710, 2018.

[28] H. Ozbek, O. B. Acikara, and B. E. Oz, "Antidiabetic activity evaluation of Onobrychis species on alloxan-induced diabetic mice," Brazilian Journal of Pharmaceutical Sciences, vol. 55, 2019.

[29] W. Tamiru, E. Engidawork, and K. Asres, "Evaluation of the effects of $80 \%$ methanolic leaf extract of Caylusea abyssinica (fresen.) fisch. \& Mey. on glucose handling in normal, glucose loaded and diabetic rodents," BMC Complementary and Alternative Medicine, vol. 12, no. 1, p. 151, 2012.

[30] N. Z. Baquer, P. Kumar, A. Taha, R. Kale, S. Cowsik, and P. McLean, "Metabolic and molecular action of Trigonella foenum-graecum (fenugreek) and trace metals in experimental diabetic tissues," Journal of Biosciences, vol. 36, no. 2, pp. 383-396, 2011.

[31] A. A. Adedapo, F. O. Jimoh, S. Koduru, A. J. Afolayan, and P. J. Masika, "Antibacterial and antioxidant properties of the methanol extracts of the leaves and stems of Calpurnia aurea," BMC Complementary and Alternative Medicine, vol. 8, no. 1, p. 53, 2008.

[32] A. Tesfaye, E. Makonnen, and S. Gedamu, "Hypoglycemic and antihyperglycemic activity of aqueous extract of Justicia Schimperiana leaf in normal and streptozotocin-induced diabetic mice," International Journal of Pharma Sciences and Research, vol. 7, no. 2, pp. 110-113, 2016.
[33] B. Rajurkar, "Phyto-pharmacological investigations of clerodendrum infortunatum gartn," International Research Journal of Pharmacy, vol. 2, pp. 130-132, 2011.

[34] A. Chika and S. O. Bello, "Antihyperglycaemic activity of aqueous leaf extract of Combretum micranthum (Combretaceae) in normal and alloxan-induced diabetic rats," Journal of Ethnopharmacology, vol. 129, no. 1, pp. 34-37, 2010.

[35] A. Toma, E. Makonnen, Y. Mekonnen, A. Debella, and S. Adisakwattana, "Antidiabetic activities of aqueous ethanol and n-butanol fraction of Moringa stenopetala leaves in streptozotocin-induced diabetic rats," BMC Complementary and Alternative Medicine, vol. 15, no. 1, p. 242, 2015.

[36] Y. Zhang, F. Feng, T. Chen, Z. Li, and Q. W. Shen, "Antidiabetic and antihyperlipidemic activities of Forsythia suspensa (Thunb.) Vahl (fruit) in streptozotocin-induced diabetes mice," Journal of Ethnopharmacology, vol. 192, pp. 256-263, 2016.

[37] S. Sudhakar Nayak and T. N. Pattabiraman, "A new colorimetric method for the estimation of glycosylated hemoglobin," Clinica Chimica Acta, vol. 109, no. 3, pp. 267-274, 1981.

[38] N. Brandstrup, J. E. Kirk, and C. Bruni, "The hexokinase and phosphoglucoisomerase activities of aortic and pulmonary artery tissue in individuals of various ages," Journal of Gerontology, vol. 12, no. 2, pp. 166-171, 1957.

[39] K. Hikaru and O. Toshitsugu, "Pathological occurrence of glucose-6-phosphatase in serum in liver diseases," Clinica Chimica Acta, vol. 4, no. 4, pp. 554-561, 1959.

[40] J. M. Gancedo and C. Gancedo, "Fructose-1,6-diphosphatase, phosphofructokinase and glucose-6-phosphate dehydrogenase from fermenting and non fermenting yeasts," Archiv fur Mikrobiologie, vol. 76, no. 2, pp. 132-138, 1971.

[41] S. Njogu, W. Arika, and D. Nyamai, "Hypoglycemic effect of aqueous and ethyl acetate leaf extract of Maytenus putterkloides in alloxan induced diabetic mice," Journal of Diabetes \& Metabolism, vol. 7, no. 685, p. 2, 2016.

[42] E. Etuk, "Animals models for studying diabetes mellitus," Agriculture and Biology Journal of North America, vol. 1, no. 2, pp. 130-134, 2010.

[43] V. Tripathi and J. Verma, "Different models used to induce diabetes: a comprehensive review," International Journal of Pharmacy and Pharmaceutical Sciences, vol. 6, no. 6, pp. 29-32, 2014.

[44] S. Sharma, M. Choudhary, S. Bhardwaj, N. Choudhary, and A. C. Rana, "Hypoglycemic potential of alcoholic root extract of Cassia occidentalis Linn. in streptozotocin induced diabetes in albino mice," Bulletin of the Faculty of Pharmacy Cairo University, vol. 52, no. 2, pp. 211-217, 2014.

[45] D. Gao, Q. Li, Z. Liu et al., "Effects ofLycium barbarum L. root bark extract on alloxan-induced diabetic mice," Therapy, vol. 4, no. 5, pp. 547-553, 2007.

[46] C. Ewenighi and U. Dimkpa, "Estimation of glucose level and body weight in alloxan induced diabetic rat treated with aqueous extract of garcinia kola," Ulutas Medical Journal, vol. 1, no. 2, pp. 26-30, 2015.

[47] T. J. Chahil and H. N. Ginsberg, "Diabetic dyslipidemia," Endocrinology and Metabolism Clinics of North America, vol. 35, no. 3, pp. 491-510, 2006.

[48] R. C. Basak, M. Chatterjee, and P. Sarma, "An overview on management of diabetic dyslipidemia," Journal of Diabetes and Endocrinology, vol. 4, no. 3, pp. 27-36, 2013.

[49] I. J. Goldberg, "Diabetic dyslipidemia: causes and consequences," Journal of Clinical Endocrinology \& Metabolism, vol. 86, no. 3, pp. 965-971, 2001. 
[50] L. Pari and R. Saravanan, "Antidiabetic effect of diasulin, a herbal drug, on blood glucose, plasma insulin and hepatic enzymes of glucose metabolism in hyperglycaemic rats," Diabetes, Obesity and Metabolism, vol. 6, no. 4, pp. 286-292, 2004.

[51] B. Gupta and N. Baquer, "Hexokinase, glucose-6-phosphate dehydrogenase and antioxidant enzymes in diabetic reticulocytes: effects of insulin and vanadate," IUBMB Life, vol. 46, no. 6, pp. 1145-1152, 1998.

[52] A. H. Gold, "The effect of diabetes and insulin on liver glycogen synthetase activation," Journal of Biological Chemistry, vol. 245, no. 4, pp. 903-905, 1970.

[53] J. D. Clark, G. F. Gebhart, J. C. Gonder, M. E. Keeling, and D. F. Kohn, "The 1996 guide for the care and use of laboratory animals," ILAR Journal, vol. 38, no. 1, pp. 41-48, 1997. 